
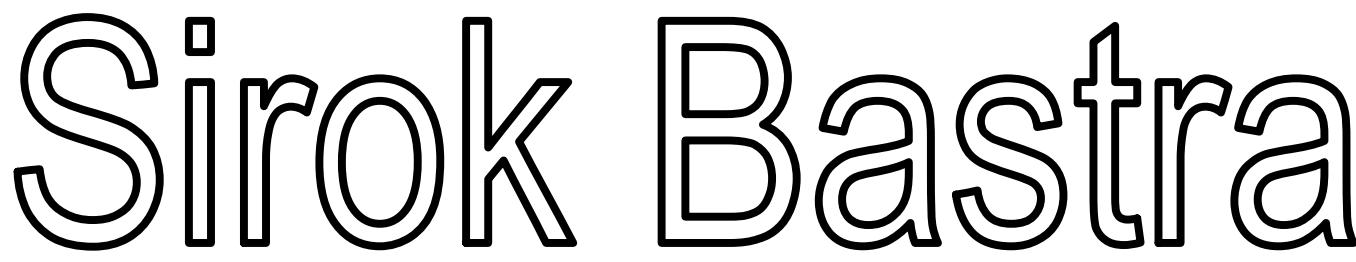

J URNAL ILMIAH KEBAHASAAN DAN KESASTRAAN

\begin{tabular}{|c|c|c|c|c|c|}
\hline $\begin{array}{c}\text { Sirok Bastra } \\
\text { Jurnal Kebahasaan dan } \\
\text { Kesastraan }\end{array}$ & Volume 5 & Nomor 2 & $\begin{array}{c}\text { Hlm. } \\
101-196\end{array}$ & $\begin{array}{c}\text { Pangkalpinang, } \\
\text { Desember } \\
2017\end{array}$ & $\begin{array}{c}\text { ISSN } \\
2354-7200\end{array}$ \\
\hline
\end{tabular}

KANTOR BAHASA KEPULAUAN BANGKA BELITUNG 


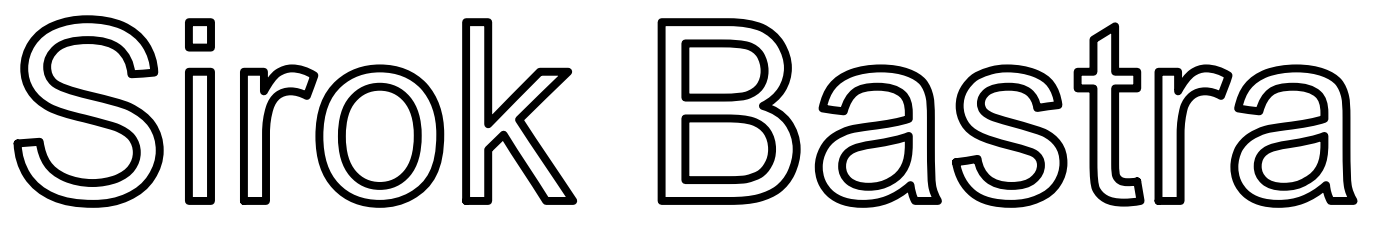

\section{J URNAL ILMIAH KEBAHASAAN DAN KESASTRAAN}

Jurnal ini merupakan wadah informasi kebahasan, kesastraan, dan pengajarannya yang memuat hasil penelitian, studi kepustakaan, dan tulisan ilmiah bidang kebahasan dan kesastraan serta pengajarannya. Sirok Bastra terbit dua kali setahun, yakni Juni dan Desember, serta terbit sejak Juni 2013.

\section{Penanggung Jawab}

Kepala Kantor Bahasa Kepulauan Bangka Belitung

Drs. Hidayatul Astar, M.Hum.

\section{Mitra Bestari}

Prof. Dr. Agus Nuryatin, M.Hum. (Bidang Sastra dan Pengajarannya)

Prof. Amrin Saragih, Ph.D., M.A. (Bidang Bahasa dan Pengajarannya)

Dr. Felicia Nuradi Utorodewo, M.Hum. (Bidang Bahasa dan Pengajarannya)

Dr. Pujiharto, M.Hum. (Bidang Sastra dan Pengajarannya)

\section{Pemimpin Redaksi}

Rahmat Muhidin, S.S.

\section{Penyunting}

Dr. Asyraf Suryadin, M.Pd.

Prima Hariyanto, S.Hum.

Sarman, S.Pd.

\section{Perancang Sampul}

Feri Pristiawan, S.S.

\section{Pengatak}

Dewi Septi Kurniawati, S.Kom.

\section{Kesekretariatan \\ Ria Anggraini, S.E. Juliati, S.E.}

\section{Alamat Redaksi dan Penerbit}

Kantor Bahasa Kepulauan Bangka Belitung

Jalan Letkol Saleh Ode No. 412, Kota Pangkalpinang, Prov. Kepulauan Bangka Belitung Telepon (0717) 438455, Faksimile(0717)9103317, Pos-el: sirokbastra@gmail.com, sirokbastra@kemdikbud.go.id

Pemuatan suatu tulisan dalam jurnal ini tidak berarti redaksi menyetujui isi tulisan tersebut. Isi tulisan menjadi tanggung jawab penulis. Tulisan telah ditinjau dan diulas oleh mitra bestari. Setiap karangan dalam jurnal ini dapat diperbanyak setelah mendapat izin tertulis dari penulis, redaksi, dan penerbit. 


\section{PENGANTAR}

Puji syukur ke hadirat Pemilik dan Pencipta semesta ini yang memiliki kuasa atas diri-Nya sendiri. Dialah Tuhan Yang Maha Esa yang telah memberikan rahmat dan hidayah-Nya sehingga Volume 5 Nomor 2 Jurnal Sirok Bastra Tahun 2017 dapat terbit tepat pada waktunya.

Pada edisi ini dimuat sepuluh tulisan, yakni lima tulisan kebahasaan, empat tulisan kesastraan, dan satu tulisan pengajaran sastra.

Dalam penelitiannya, Hotnida Novita Sary menganalisis iklan komersial Meikarta yang telah membuat perusahaan tersebut berhasil mencatatkan penjualan yang fantastis. Penelitian yang dilakukannya menggunakan pisau bedah analisis wacana kritis Fairclough (1989). Iklan Meikarta membandingkan kesuperioritasan mereka dibandingkan kota metropolitan lain, seperti Jakarta. Meikarta juga menanamkan ideologi bagi masyarakat kota besar bahwa kota metropolitan saat ini sudah tidak aman, kotor, dan macet.

Dalam makalahnya, Hidayatul Astar mengkaji realisasi konsep bahasa Indonesia ke dalam bahasa Rejang. Menurutnya, masyarakat Rejang tidak memiliki konsep (kata atau istilah) yang cukup untuk mewakili pikiran dan perasaan tertentu ketika berkomunikasi, terutama yang terkait dengan konsep kehidupan modern atau yang sesuai dengan perkembangan zaman. Karena itu, bahasa Rejang perlu memungut atau mengambil dari bahasa lain, khususnya dari bahasa Indonesia. Realisasi bentuk konsep yang ditemukan adalah realisasi tanpa perubahan dan realisasi dengan perubahan. Berdasarkan data, realisasi perubahan dalam sebuah konsep dapat satu kali atau lebih. Realisasi perubahan itu berupa penghilangan, penggantian, dan penambahan bunyi vokal atau konsonan tertentu pada posisi tertentu. Terjadinya perubahan realisasi bunyi bahasa Indonsia ke dalam bahasa Rejang disebabkan oleh keinginan penutur bahasa Rejang dan adaptasi terhadap bunyi yang sudah ada.

Dalam kajiannya, Mardi Nugroho membahas pembentukan kata dalam bahasa Talondo di Sulawesi Barat. Hasil analisis data menunjukkan bahwa ada tiga macam cara pembentukan kata dalam bahasa Talondo, yaitu afiksasi, reduplikasi, dan pemajemukan. Pembentukan kata dengan afiksasi terdiri atas pembentukan kata dengan prefiksasi, konfiksasi, infiksasi, dan sufiksasi. Pembentukan kata dengan reduplikasi terdiri atas reduplikasi murni, reduplikasi sebagian, dan reduplikasi yang berkombinasi dengan afiksasi.

Dalam kajiannya, Muhammad Fadely membahas makna dan bentuk pemakaian eufemisme dan disfemisme dalam feature karya Ruslan Ismail Mage yang bermanfaat bagi pengajaran bahasa Indonesia dan pengembangan bahasa di media massa cetak. Hasil analisis menunjukkan bahwa pemakaian eufemisme lebih banyak daripada pemakaian disfemisme. Berdasarkan simpulan tersebut, peneliti menyarankan bahwa dalam menyampaikan suatu informasi kepada khalayak umum hindari tulisan-tulisan yang dapat mengaburkan dan tidak terus terang demi maksud-maksud tertentu.

Dalam kajiannya, Asri Soraya Afsari membahas karakteristik bahasa yang digunakan dalam iklan komersial ponsel yang berada di Kota Bandung. Hasil penelitian menunjukkan bahwa bentuk dan fungsi bahasa yang digunakan dalam iklan ponsel di Kota Bandung berupa penulisan huruf kapital secara keseluruhan dan penulisan huruf kapital pada awal kata. Bahasa iklan ponsel memiliki fungsi informatif dan konatif (persuatif).

Dalam tulisannya, Erwin Wibowo mendeskripsikan makna semiotik budaya Lampung yang ada di dalam antologi Kitab Cerpen Perempuan di Rumah Panggung. Hasil penelitian mengungkapkan ikon, indeks, dan simbol budaya Lampung melalui pendekatan semiotik yang dipakai dalam Kitab Cerpen Perempuan di Rumah Panggung karya Isbedy Stiawan ZS dan memberi deskripsi tentang ikon, indeks, dan simbol tesebut.

Dalam penelitiannya, Prima Hariyanto membahas penokohan dalam Kitab Omong Kosong yang mengambil cerita epos Ramayana. Dalam novel ini, pengarang mengubah pola cerita. Tokoh sentral dalam cerita ini bukan lagi Rama dan Sinta, tetapi Maneka dan Satya. Ceritanya bukan lagi kisah cinta Rama dan Sinta, tetapi kisah perjalanan Maneka dan Satya dalam mencari Kitab Omong Kosong ciptaan Hanoman. Tokoh Rama tidak lagi diceritakan sebagai kesatria yang baik, tetapi sebagai raja yang membawa bencana bagi rakyat di muka bumi.

Dalam kajiannya, Dian Anggraini mengkaji intertekstual lima puisi Indonesia yang berisi tentang sosok wanita yang disebut ibu, yaitu "Ibu Dehulu" (Amir Hamzah), "Ibu” (Chairil Anwar), "Sajak Ibu” (Wiji Thukul), 
"Bunda Air Mata" (Emha Ainun Najib"), dan "Ibu” (K.H. Mustofa Bisri). Hasil telaah itu membuktikan bahwa kelima puisi tersebut merupakan mosaik, kutipan-kutipan, penyerapan, dan perspektif yang beragam terhadap sosok ibu. Setiap penyair mengungkapkan sisi ibu dari pandangan yang berbeda.

Dalam kajiannya, Yuliadi M.R. membahas makna ground dalam cerpen "Uak dan Burung Gagak" dengan pendekatan objektif melalui teori semiotik Pierce. Berdasarkan kajian, terungkap bahwa makna ground dalam cerpen Uak dan Burung Gagak, yaitu ground qualisign berupa warna hitam, sinsign berupa suara koakkoak, dan legisign berupa perilaku mengitari rumah.

Dalam tulisannya, Abdul Azis dan Hajrah membahas dongeng sebagai bahan pembelajaran di sekolah dasar. Data penelitian ini adalah dongeng Cerita Si Jingkiriq, I Kukang, Nenek Pakande, La Dana dan Kerbaunya, dan Puang Tedong. Hasil analisis data dan temuan menunjukkan bahwa rata-rata penilaian responden untuk dongeng sebesar 3,75 (kategori layak dijadikan bahan ajar). Bahan ajar yang dapat digunakan untuk tingkat SD adalah dongeng yang isinya sesuai dengan karakteristik, pengalaman, dan kebutuhan siswa.

Kami mengucapkan terima kasih kepada para penulis yang telah bersedia menerbitkan karya mereka pada edisi ini. Para penulis merupakan peneliti, pakar, dosen, dan mahasiswa dari berbagai perguruan tinggi dan instansi. Terima kasih juga kami sampaikan kepada para mitra bestari kami yang telah memberi ulasan terhadap tulisan-tulisan yang masuk ke redaksi.

Demi memenuhi keberagaman isi dan penulis, Sirok Bastra membuka kesempatan bagi para peneliti dan penulis menyampaikan hasil penelitian dan pemikiran mutakhir dalam bidang kebahasaan, kesastraan, dan pengajarannya. 


\section{UCAPAN TERIMA KASIH UNTUK MITRA BESTARI}

Redaksi Sirok Bastra mengucapkan terima kasih kepada para mitra bestari yang telah meninjau, menimbang, dan mengulas makalah-makalah yang diterbitkan dalam Sirok Bastra Volume 5 Nomor 2, edisi Desember 2017, yakni

Prof. Dr. Agus Nuryatin, M.Hum.

Bidang Sastra dan Pengajarannya

Universitas Negeri Semarang

Semarang, Jawa Tengah

Prof. Amrin Saragih, Ph.D., M.A.

Bidang Bahasa dan Pengajarannya

Universitas Negeri Medan

Medan, Sumatra Utara

Dr. Felicia Nuradi Utorodewo, M.Hum.

Bidang Bahasa dan Pengajarannya

Universitas Indonesia

Depok, Jawa Barat

\section{Dr. Pujiharto, M.Hum.}

Bidang Sastra dan Pengajarannya

Universitas Gadjah Mada

Yogyakarta, Daerah Istimewa Yogyakarta 


\section{DAFTAR ISI}

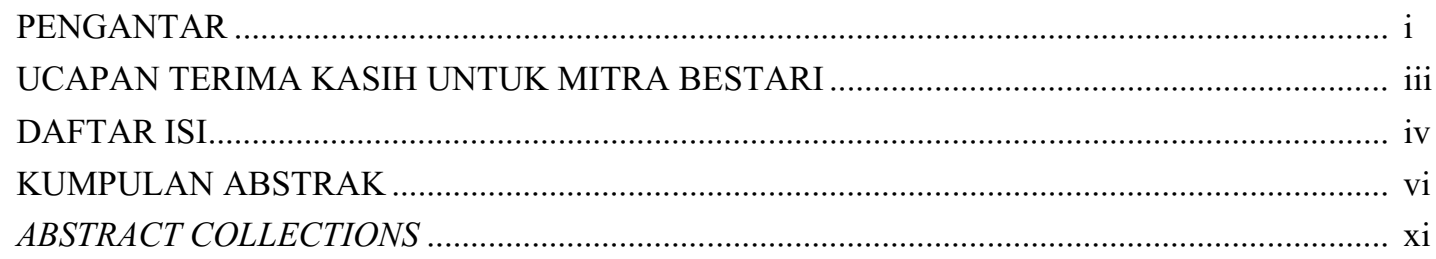

ANALISIS WACANA KRITIS IKLAN KOMERSIAL MEIKARTA

(Critical Discourse Analysis of Meikarta Commercial Advertising)

Hotnida Novita Sary $101-111$

REALISASI KONSEP BAHASA INDONESIA DALAM BAHASA REJANG

(Realization of Indonesian Concept Into Rejang Language)

Hidayatul Astar. $113-121$

PEMBENTUKAN KATA DALAM BAHASA TALONDO

(The Word Formation in Talondo Language)

Mardi Nugroho $123-129$

EUFEMISME DAN DISFEMISME PADA FEATURE-FEATURE KARYA RUSLAN ISMAIL MAGE

(Euphemism and Disphemism in The Features by Ruslan Ismail Mage)

Muhammad Fadely $131-139$

KARAKTERISTIK PENGGUNAAN BAHASA DALAM IKLAN PONSEL DI KOTA BANDUNG

(The Characteristic of Language Usage on Mobile Phone Advertisement in Bandung) Asri Soraya Afsari $141-151$

SIMBOL BUDAYA LAMPUNG DALAM KITAB CERPEN PEREMPUAN DI RUMAH PANGGUNG KARYA ISBEDY STIAWAN Z.S.: KAJIAN SEMIOTIKA

(Lampung Cultural Symbols in Kitab Cerpen Perempuan di Rumah Panggung by Isbedy Stiawan Z.S.: a Semiotic Analysis)

Erwin Wibowo $153-161$

PENOKOHAN DALAM KITAB OMONG KOSONG KARYA SENO GUMIRA AJIDARMA (Characterization in Kitab Omong Kosong by Seno Gumira Ajidarma)

Prima Hariyanto $163-169$

WANITA ISTIMEWA: KAJIAN INTERTEKSTUAL TERHADAP PUISI-PUISI TENTANG IBU

(Special Woman: Intertextual Study of Poems About Mother) 
BURUNG GAGAK SEBUAH TANDA: MAKNA GROUND DALAM CERPEN UAK DAN BURUNG GAGAK

(Brids Crow A Sign: Ground Meaning in Uak and Burung Gagak Short Story)

Yuliadi M.R.

DONGENG SEBAGAI BAHAN PEMBELAJARAN BAHASA INDONESIA DI SEKOLAH

DASAR

(Folktale as Indonesian Language Learning Material in Elementary School)

Abdul Azis dan Hajrah

$191-196$ 
Muhammad Fadely: Eufemisme dan Disfemisme pada Feature-Feature Karya Ruslan Ismail Mage

\title{
EUFEMISME DAN DISFEMISME PADA FEATURE-FEATURE KARYA RUSLAN ISMAIL MAGE
}

\section{Euphemism and Disphemism in The Features by Ruslan Ismail Mage}

\author{
Muhammad Fadely \\ STKIP Muhammadiyah Bangka Belitung \\ Jalan K.H. Ahmad Dahlan, Pangkalanbaru, Kepulauan Bangka Belitung \\ Pos-el: fadelyoke@gmail.com
}

(diterima 28 Juli 2017, disetujui 17 September 2017, revisi terakhir 5 Desember 2017)

\begin{abstract}
Abstrak
Penelitian ini membahas makna dan bentuk pemakaian eufemisme dan disfemisme dalam feature karya Ruslan Ismail Mage. Penelitian ini bertujuan untuk mendekripsikan pemakaian makna dan bentuk eufemisme dan disfemisme yang bermanfaat bagi pengajaran bahasa Indonesia dan pengembangan bahasa di media massa cetak. Sumber data dalam penelitian ini adalah feature-feature yang dimuat dalam buku Campus Undercover karya Ruslan Ismail Mage. Objek penelitian ini adalah pemakaian eufemisme dan disfemisme berupa bentuk dan maknanya. Pengumpulan data dilakukan dengan teknik dokumentasi, sedangkan data dianalisis dengan distribusi, ekspansi, kolokasi, dan komponen makna. Hasil analisis menunjukkan bahwa pemakaian eufemisme lebih banyak daripada pemakaian disfemisme. Berdasarkan simpulan tersebut, peneliti menyarankan bahwa dalam menyampaikan suatu informasi kepada khalayak umum hindari tulisan-tulisan yang dapat mengaburkan dan tidak terus terang demi maksud-maksud tertentu.
\end{abstract}

Kata kunci: modul, pendekatan saintifik, menulis feature

\begin{abstract}
this research examine the meaning and use form of euphemism and disphemism. This research have a purpose to describe the usage of the meaning dan form of euphemism and disphemism which are useful for Indonesian language teaching dan language development in mass media. Source of data in this research are the features from press published in Campus Undercover book by Rusman Ismail Mage. The object of the research is the usage of euphemism and disphemism in the form and the meaning. Data collection is carried out by documentation technique and the data were analyzed with the distribution, collocation, and components of meaning. The results of the analysis showed that the usage of euphemism is more than the usage of disphemism. Based on the conclusion, researchers recommend in conveying message to public to avoid obscure writing for spesific purpose.
\end{abstract}

Keywords: module, scientific approach, writing feature

\section{PENDAHULUAN}

\subsection{Latar Belakang}

Bahasa mempunyai peranan penting sebagai alat komunikasi dengan lambang bunyi yang bersifat arbitrer dan merupakan saluran perumusan maksud, melahirkan perasaan, dan memungkinkan terciptanya kerja sama antarwarga (Keraf, 1993:4). Bahasa digunakan pula pada bidang jurnalistik. Bahasa jurnalistik didasarkan pada bahasa baku yang tidak mengabaikan kaidah-kaidah tata bahasa serta memerhatikan ejaan yang benar. Bahasa jurnalistik membutuhkan kreativitas tinggi sebagai suatu kemenarikan bahasa. Untuk itu, pengelola media massa cetak, khususnya wartawan dituntut untuk memiliki keterampilan menulis yang baik.

Feature merupakan salah satu produk jurnalistik media massa cetak berupa tulisan yang berisi fakta objektif dan bersifat khas. Bentuknya narasi (mengisahkan) dan disampaikan secara langsung, tidak terikat aktualitas, dan selalu membawa pesan moral tertentu kepada khalayak. Gaya bahasa yang digunakan indah dan menggoda, serta terkadang direkayasa untuk menghibur (Sumadiria, 2005:155). 
Saat ini feature-feature yang termasuk rumpun berita (news) dalam media massa cetak cenderung menggunakan eufemisme untuk menutupi maksud tertentu dengan alasan politis dan kemenarikannya sehingga tidak lugas dalam menyampaikan makna yang sesungguhnya. Bahkan tidak itu saja, menurut Chaer (2002:145) disfemisme yang merupakan kebalikan eufemisme juga sengaja digunakan untuk memberi tekanan tanpa terasa kekasarannya, misalnya ungkapan masuk kotak dipakai untuk mengganti kata kalah.

Menurut Masri (2001:63) hal-hal yang melatarbelakangi penggunaan disfemisme dalam media massa cetak adalah untuk mengungkapkan kejengkelan bentuk tolak kepada perasaan kesal, perasaan mendongkol, dan kekecewaan seseorang. Oleh sebab itu, tidak mengherankan jika disfemisme digunakan sebagai senjata untuk menghadapi orang lain atau pelampiasan kemarahan. Perubahan rezim pemerintahan dari Orde Baru ke Orde Reformasi juga telah menimbulkan perubahan dalam pemakaian gaya bahasa media massa.

\subsection{Masalah}

Permasalahan yang diuraikan dalam penelitian ini adalah bagaimana makna dan bentuk eufemisme dan disfemisme yang terdapat pada feature-feature dalam buku Campus Undercover.

\subsection{Tujuan}

Penelitian ini bertujuan untuk mendeskripsikan makna dan bentuk eufemisme dan disfemisme yang terdapat pada feature-feature dalam buku Campus Undercover.

\subsection{Manfaat}

Penelitian ini memberikan sumbangan bagi guru tentang pengajaran bahasa Indonesia, khususnya gaya bahasa eufemisme dan disfemisme serta bermanfaat untuk pembinaan dan pengembangan bahasa pada media massa cetak.

\subsection{Metode}

Metode yang digunakan dalam penelitian ini adalah metode deskriptif (Arikunto, 1987:120). Penggunaan metode ini diharapkan dapat mengungkapkan makna-makna dan bentuk-bentuk yang terdapat dalam buku Campus Undercover.

Penelitian ini dilakukan dengan dua pendekatan, yaitu pendekatan analitik dan operasional. Pendekatan analitik merupakan pendekatan untuk mencari perbedaan dan persamaan komponenkomponen makna pada bentuk-bentuk kebahasaan yang bersinonim, sedangkan pendekatan operasional merupakan pendekatan yang mencari persamaan dan perbedaan penggunaan bentuk kebahasaan yang bersinonim dalam berbagai konteks. Dua pendekatan tersebut digunakan untuk melihat distribusi dan kolokasi atau kelaziman pemakaiannya (Pateda, 2001:86).

Sumber data dalam penelitian ini adalah 25 judul feature dalam buku Campus Undercover. Data dikumpulkan dengan teknik dokumentasi, yakni teknik yang dilakukan untuk mencari variabel berupa catatan, transkrip, buku, surat kabar, majalah, prasasti, notulen rapat, agenda, dan sebagainya (Arikunto, 1998:236).

\subsubsection{Teknik Pengolahan Data}

Dalam pengolahan data, teknik yang digunakan adalah teknik subtitusi dengan mencari persamaan dan perbedaan eufemisme dan disfemisme sebagai bentuk pengganti (Sudaryanto, 1993:54). Sebagai contoh, perhatikan kalimat berikut.

Krisis ekonomi cukup lama $\left\{\begin{array}{l}\text { mencekik } \\ \text { menindas }\end{array}\right\}$ negeri ini.

Dalam kalimat di atas, kata mencekik dipilih sebagai disfemisme dari kata menindas yang digunakan untuk memberikan penekanan bahwa krisis ekonomi sudah benar-benar menyusahkan rakyat. Pengungkapan ini ditekankan dengan kata mencekik.

Berdasarkan distribusinya kata mencekik dan kata menindas memiliki distribusi yang berbeda, dilihat dari cakupan maknanya. Kata mencekik memiliki cakupan makna yang berarti 'memegang atau mencengkeram leher sehingga tidak dapat bernafas' sedangkan kata menindas bermakna 'menindih/menghimpit, menekan kuat-kuat'. Hal ini dapat dilihat dari kalimat berikut. 
Penjahat itu $\left\{\begin{array}{c}\text { mencekik } \\ * \text { menindas }\end{array}\right\}$ korbannya hingga tewas. Pemerintah Israel sering $\left\{\begin{array}{c}\text { menindas } \\ * \text { mencekik }\end{array}\right\}$ warga Palestina.

Menurut pengertian paradigmatik, distribusi adalah kemungkinan subtitusi unsur dalam kalimat lain secara vertikal dan posisinya sama dalam kalimat (Masri, 2001:65). Teknik ganti dilaksanakan dengan mengganti unsur-unsur tertentu yang sama maknanya dengan tolak ukur kamus sinonim dan Kamus Besar Bahasa Indonesia.

Selanjutnya untuk mencari perbedaan dan persamaan kolokasi antara bentuk eufemisme dan disfemisme sebagai bentuk pengganti makna, digunakan teknik perluasan (ekspansi) (Sudaryanto, 1993:55). Teknik perluasan (ekspansi) dilakukan dengan melihat kelaziman pemakaian kata atau frasa dalam masyarakat.

Berikut ini contoh pemakaian makna eufemisme pada feature-feature (karangan-karangan khas) dalam buku Campus Undercover.

a. Makna eufemisme yang berhubungan dengan kenyataan sosial yang dianggap sesuatu yang buruk: Pakaian yang terlalu banyak jendelanya (terbuka).

b. Makna eufemisme yang berhubungan dengan nasib yang tidak menyenangkan: Nilainya tidak bagus, bahkan tidak lulus (buruk).

c. Makna eufemisme yang berhubungan dengan sifat yang jelek: Biarkan partai itu menggoda dengan caranya sendiri, tanpa harus memberikan reaksi dulu (memengaruhi).

Berikut ini contoh pemakaian bentuk-bentuk eufemisme pada feature (karangan khas) dalam buku Campus Undercover.

a. Bentuk pengambilan kata asing: Semangat muda membawa radikalisme dalam gerakan politik (kekerasan).

b. Bantuk penggunaan kata yang lebih panjang: Mahasiswa yang imannya tidak kuat akan melakukan hal-hal yang melanggar norma kesopanan dan kesusilaan (lemah). c. Bentuk manipulasi bahasa: Negara maju mengembuskan angin globalisasi pasar kepada negara yang sedang berkembang dengan harapan bisa mendikte negara tersebut (miskin).

d. Bentuk metafora: Krisis ekonomi yang berkepanjangan membuat beberapa perusahaan besar gulung tikar (bangkrut).

Pemakaian disfemisme pada penelitian ini cenderung mengandung makna emotif, nilai rasa atau berkonotasi kasar dengan mengeraskan atau menguatkan makna. Contohnya sebagai berikut.

a. Suatu milenium menuntut kualitas SDM yang unggul (menginginkan).

b. Kebutuhan hidup semakin mencekik (meningkat).

c. Bisnis rumah kos-kosan semakin menjamur di Yogyakarta (bertambah).

\section{KERANGKA TEORI}

\subsection{Gaya Bahasa}

Gaya bahasa dapat dibedakan atas beberapa jenis. Salah satunya adalah gaya bahasa berdasarkan langsung atau tidaknya makna berupa penyimpangan evaluatif, atau secara motif dari bahasa biasa, entah dalam ejaan, pembentukan kata, konstruksi (kalimat, klausa, frasa) atau aplikasi sebuah istilah untuk memperoleh kejelasan, penekanan, hiasan, humor, atau sesuatu efek lain (Keraf, 1990:129).

\subsection{Eufemisme}

Eufemisme adalah bentuk ungkapan untuk mengganti kata-kata yang dinilai kurang sopan dan kasar dengan kata-kata yang lebih halus. Natawidjaya (1986:84) mengatakan bahwa ungkapan pilihan kata sebagai pelemah dari pernyataan yang akan dikemukakan karena tabu atau menjaga ketersinggungan hati orang lain.

Eufemisme sebenarnya tidak hanya berkaitan dengan penggantian kata yang bernilai rasa kasar dengan kata yang bernilai halus saja, tetapi juga berhubungan dengan kata pantang atau tabu. Oleh karena itu, pemakaian eufemisme banyak berkaitan dengan manusia, baik yang berhubungan dengan tubuh, sifat manusia, perbuatan manusia, dan 
kenyataan sosial yang dianggap buruk. Sunarso (1998:71) mengemukakan tentang makna-makna eufemisme sebagai berikut.

a. Kematian, misalnya mendahului kita, menghadap Tuhan YME untuk menggantikan mati.

b. Seks, misalnya memenuhi kebutuhan biologis untuk menggantikan bersetubuh.

c. Penyakit cacat tubuh, misalnya terganggu penglihatannya untuk menggantikan buta.

d. Pengeluaran kotoran badan, misalnya ke belakang untuk menggantikan kakus.

e. Kenyataan sosial yang dianggap buruk, misalnya tunawisma untuk menggantikan gelandangan.

f. Nasib yang tidak menyenangkan, misalnya pembebastugasan untuk menggantikan pemecatan.

g. Sifat yang jelek, misalnya kurang rajin untuk menggantikan malas.

h. Hal yang dapat menimbulkan bahaya, misalnya raja hutan untuk menggantikan harimau.

Menurut Badudu (1986:40), terdapat tiga macam eufemisme, yaitu (1) unsur serapan atau pengambilan kata asing, misalnya you (kau); (2) menggunakan ungkapan/uraian yang lebih panjang, misalnya berak (buang air besar); (3) manipulasi bahasa, misalnya kelaparan (kekurangan makanan).

\subsection{Disfemisme}

Disfemisme adalah kebalikan dari eufemisme, yakni ungkapan dengan kata-kata kasar dan kurang sopan. Menurut Alwi (dikutip Masri, dkk) disfemisme merupakan bentuk pengasaran yang dipakai untuk menghujat atau untuk mengeraskan makna. Chaer (2002:145) mengatakan bahwa disfemisme merupakan usaha untuk menggantikan kata-kata yang maknanya halus atau bermakna biasa dengan kata-kata yang bermakna kasar. Biasanya disfemisme dipakai orang dalam situasi yang tidak ramah atau menunjukkan kejengkelan dan untuk mengeraskan makna. Sebagai contoh, kalimat Akhirnya regu bulutangkis kita berhasil menggondol pulang piala Thomas Cup itu. Kata menggondol biasa digunakan untuk binatang, misalnya Anjing menggondol tulang.
Kecenderungan untuk melebih-lebihkan suatu keadaan untuk mengungkapkan kekesalan biasa menggunakan kata atau ungkapan dengan mengeraskan maknanya. Jika dilihat dari nilai rasa atau makna emotif, hal tersebut dapat disebut konotasi keras, misalnya Pejabat itu uangnya berpeti-peti (Tarigan, 1995:72).

Makna emotif atau nilai rasa dapat bersifat positif (baik, sopan, hormat, dan sakral) dan dapat pula bersifat negatif (kasar, jelek, kotor, tidak sopan, dan porno) (Djajasudarma, 1993:11). Pemakaian disfemisme dalam penelitian ini adalah penggantian kata (atau bentuk lain) yang bernilai rasa positif atau netral dengan kata (atau bantuk lain) yang bernilai kasar atau negatif.

Dilihat dari nilai rasanya, pemakaian disfemisme menunjukkan kecenderungan seperti disfemisme kata bejat dari kata asusila (menyeramkan), disfemisme kata dicincang dari kata dibunuh (mengerikan), disfemisme kata dajal dari kata setan (menakutkan), dan disfemisme kata borok dari kata masalah (Masri, dkk., 2001:72).

Menurut Chaer (2002:87) bentuk disfemisme yang bersinonim dapat berupa kata dengan kata, kata dengan frasa, dan frasa dengan frasa.

\subsection{Eufemisme dan Disfemisme dalam Kajian Semantik}

Eufemisme digunakan untuk menggantikan ungkapan yang dirasakan kasar dengan bahasa yang halus sehingga enak didengar. Begitu pula sebaliknya, disfemisme digunakan untuk menggantikan ungkapan yang halus, sopan, dan menyenangkan dengan bahasa yang lebih kasar. Kajian tentang eufemisme dan disfemisme berkaitan dengan makna yang termasuk dalam lingkup semantik.

Semantik merupakan salah satu tataran analisis bahasa yang mempelajari tentang makna kata. Makna adalah konsep dari "lambang" atau "tanda" yang berarti maksud dari kata/ungkapan. Setiap orang memiliki konsep makna tersendiri dalam pikirannya yang menyebabkan terjadinya perubahan makna kata. Faktor-faktor yang menyebabkan perubahan makna kata tersebut adalah (1) 
perkembangan ilmu pengetahuan dan teknologi; (2) perkembangan sosial dan budaya; (3) perkembangan bidang pemakaian; (4) adanya asosiasi; (5) pertukaran tanggapan indra; (6) perbedaan tanggapan; (7) adanya penyingkatan; (8) proses gramatikal; dan (9) pengembangan istilah. Sebagai akibat dari perubahan-perubahan tersebut terjadilah berbagai perubahan yang meliputi perluasan, penyempitan, perubahan total, penghalusan, dan pengasaran (Chaer, 2002:145).

Dalam kerangka semantik, eufemisme dan disfemisme dapat dikaji dalam sinonim. Verhaar (1988:132) menyatakan bahwa sinonim adalah ungkapan (kata, frasa, atau kalimat) yang kurang lebih sama maknanya dengan suatu ungkapan lain. Secara harfiah, sinonim berarti 'nama lain untuk benda yang sama'.

\subsection{Feature}

Feature merupakan salah satu produk jurnalistik media massa cetak berupa tulisan yang berisi fakta objektif, tetapi bersifat khas karena bersifat narasi (mengisahkan), disampaikan secara langsung, tidak terikat aktualitas, dan selalu membawa pesan moral tertentu kepada khalayak dengan gaya bahasanya yang indah dan menggoda; terkadang direkayasa untuk menghibur (Sumadiria, 2005:155).

Cahya (2012:15) menjelaskan bahwa feature merupakan jenis berita ringan yang mendalam, mengibur, dan enak untuk disimak, dan biasanya menggunakan teknik pengisahan sebuah cerita. Tulisan feature memberikan penekanan pada faktafakta yang dianggap mampu menghibur dan memunculkan empati pembaca. Ciri khas sebuah feature, yaitu mengandung unsur sastra. Walaupun feature ditulis dengan gaya menulis fiksi, informasinya tetap informatif dan aktual. Unsurunsur tulisan feature adalah kreatif, informatif, menghibur, dan tidak dibatasi waktu

Berita kisah atau feature adalah tulisan yang dapat menyentuh perasaan ataupun menambah pengetahuan. Berita kisah ini tidak terikat aktualitas karena nilai utamanya adalah manusiawinya (Chaer, 2010:17). Senada dengan pendapat di atas Romli (2009:22) menjelaskan feature merupakan sebuah "karangan khas" yang menuturkan fakta, peristiwa, atau proses disertai penjelasan riwayat terjadinya, duduk perkaranya, proses pembentukannya, dan cara kerjanya. Sebuah feature umumnya mengedepankan unsur why dan how sebuah peristiwa.

Feature merupakan karangan kreatif yang ditulis dengan teknik berkisah dalam rangka menginformasikan sesuatu yang menyenangkan pembaca. Feature ini dikategorikan ke dalam artikel jurnalistik yakni ragam tulisan opini berbentuk ringkas padat untuk surat kabar yang ditulis dari sudut pandang penulisnya. Feature didefinisikan sebagai karangan proses berbentuk ringkas padat yang disajikan secara naratif dan sarat mengandung unsur human interest (makna kemanusiaan). Feature berkesan lebih ringan, lebih menghibur, dan lebih mengajak pembacanya merenungi makna kemanusiaan (Wibowo, 2007:11).

Kusumaningrat (2012:219) menjelaskan feature bisa berupa berita, bisa juga berupa karangan, tetapi dengan syarat-syarat tertentu. Gaya penulisannya ditekankan pada emosi dan sentuhan perasaan manusia. Berdasarkan pendapat di atas dapat disimpulkan bahwa feature adalah karangan khas yang berisi fakta-fakta, tetapi kental dengan keindahan bahasa untuk memikat hati pembaca karena bersifat mengisahkan. Feature merupakan artikel ringan yang kreatif, terkadang bersifat subjektif dengan gaya penulisan yang tidak terlalu baku dan kaku seperti berita.

\section{HASIL DAN PEMBAHASAN}

Selain informasi yang didapatkan, ketertarikan pembaca terhadap media cetak, baik itu surat kabar, tabloid, maupun majalah adalah pemakaian bahasa yang menarik yang ditimbulkan oleh pemakaian gaya bahasa, dalam hal ini, gaya bahasa yang terdapat pada feature. Penggunaan gaya bahasa tidak hanya digunakan di bidang sastra, tetapi juga di bidang media cetak. Dalam penelitian ini, dianalisis penggunaan gaya bahasa eufemisme dan disfemisme feature media cetak dalam Campus Undercover. 


\subsection{Makna Eufemisme}

Dari delapan bidang makna eufemisme menurut Sunarso (1998), hanya tiga tipe yang terdapat dalam feature Campus Undercover, yakni (a) eufemisme yang berhubungan dengan kenyataan sosial yang dianggap buruk; (b) eufemisme yang berhubungan dengan nasib yang tidak menyenangkan; dan (c) eufemisme yang berhubungan dengan sifat jelek. Bidang makna yang tidak terdapat dalam penelitian ini adalah makna yang berhubungan dengan seks, kematian, cacat tubuh, pengeluaran kotoran, dan hal yang menimbulkan bahaya.

Eufemisme yang berhubungan dengan kenyataan sosial yang dianggap sesuatu yang buruk adalah kata atau frasa dalam tataran kalimat yang berkaitan dengan kenyataan sosial yang tidak menyenangkan dan dianggap sebagai sesuatu yang buruk, seperti tampak pada contoh berikut.

a. Telinganya sudah $\left\{\begin{array}{c}\text { tidak mendengar } \\ \text { tuli }\end{array}\right\}$ terhadap reaksi masyarakatnya.

Dalam kalimat di atas terlihat bahwa frasa tidak mendengar merupakan eufemisme dari kata tuli. Kata tersebut merupakan ungkapan yang menyatakan masyarakat yang tidak peduli lagi terhadap lingkungan sekitarnya sebagai bentuk penghalus. Namun, dilihat dari distribusinya, frasa tidak mendengar dan kata tuli memiliki distribusi yang berbeda. Dilihat dari cakupan maknanya, maksud ungkapan tidak mendengar adalah tidak mau peduli terhadap suatu keadaan, sedangkan kata tuli cenderung kepada penyakit. Perhatikan contoh kalimat berikut.

Tuli akan kita alami pada usia tua.

* Tidak mendengar akan kita alami pada usia tua.

Berdasarkan kolokasinya, frasa tidak mendengar digunakan untuk menyatakan informasi yang diterima karena kelalaian (kesengajaan), sedangkan kata tuli lazim digunakan sebagai penyakit.

b. Krisis ekonomi yang berkepanjangan membuat beberapa perusahaan $\left\{\begin{array}{c}\text { gulung tikar } \\ \text { bangkrut }\end{array}\right\}$.
Pada kalimat di atas, ungkapan gulung tikar dimaksudkan untuk menggantikan kata bangkrut atau merugi. Makna konotasi, makna emotif, atau nilai rasa yang lebih halus ditimbulkan oleh frasa gulung tikar sebagai bentuk pengganti dari kata bangkrut yang kasar. Wujud frasa yang bermakna emotif dalam tipe ini bermakna metafora.

c. Kita hanya akan menjadi $\left\{\begin{array}{l}\text { papan catur } \\ \text { pemfasilitas }\end{array}\right\}$ bangsabangsa lain.

Pada kalimat di atas, frasa papan catur digunakan sebagai eufemisme dari kata pemfasilitas dan untuk menghaluskan makna agar enak didengar. Selain itu, frasa ini mengaburkan makna karena adanya ketidaklangsungan arti sehingga maknanya tidak langsung dapat ditangkap. Dilihat dari cakupan maknanya, distribusi frasa papan catur dan kata pemfasilitas berbeda, seperti dalam contoh berikut.

$\left\{\begin{array}{l}\text { Papan catur } \\ \text { Pemfasilitas }\end{array}\right\}$ itu terbuat dari emas.

Dalam lomba itu, PT Indomobil bertindak sebagai $\{$ pemfasilitas

$\{$ * papan catur $\}$ nya.

Kedua kalimat di atas menunjukkan bahwa frasa papan catur tidak dapat berdistribusi. Dilihat dari kolokasinya, kata pemfasilitas menerangkan orang, lembaga, atau instansi yang merupakan sponsor suatu kegiatan, sedangkan frasa papan catur lazim menerangkan alas tempat bermain catur.

\subsection{Bentuk Eufemisme}

\subsubsection{Pengambilan Kata Asing}

Bentuk pengambilan kata asing dapat dilihat dalam contoh berikut.

a) Kata hedonis eufemisme dari kata keduniawian

b) Kata dekadensi eufemisme dari kata kemerosotan

c) Kata mengeksploitasi eufemisme dari kata memanfaatkan 


\subsubsection{Penggunaan Ungkapan/Uraian Lebih Panjang}

Bentuk penggunaan ungkapan/uraian lebih panjang dapat dilihat dalam contoh berikut.

a) Frasa tidak mendengar eufemisme dari kata tuli

b) Frasa tidak bagus eufemisme dari kata jelek

c) Frasa tidak berpendidikan eufemisme dari kata bodoh

d) Frasa tidak kuat eufemisme dari kata lemah

e) Frasa gulung tikar eufemisme dari kata bangkrut

\subsubsection{Manipulasi Bahasa}

Bentuk penggunaan manipulasi bahasa dapat dilihat dalam contoh kalimat Keran demokrasi baru dibuka beberapa tahun lalu, tepatnya ketika Presiden Soeharto diturunkan oleh mahasiswa. Kata keran merupakan eufemisme dari kata kebebasan.

\subsection{Makna Disfemisme}

Disfemisme digunakan pada kata yang mengandung makna emotif, nilai rasa, atau mempunyai konotasi lebih kasar untuk melebih-lebihkan suatu keadaan, seperti terlihat dalam kalimat berikut.

a. Inul $\left\{\begin{array}{c}\text { membungkus } \\ \text { mengenakan }\end{array}\right\}$ tubuhnya dengan

busana yang super ketat ditambah dengan sedikit goyangan.

Dalam kalimat di atas, kata membungkus dipilih sebagai disfemisme dari kata mengenakan yang digunakan untuk menunjukkan kekesalan terhadap Inul karena busananya yang sangat seksi dan goyangannya yang vulgar.Namun, dilihat dari distribusinya dan cakupan maknanya, kata membungkus dan kata mengenakan berbeda distribusi. Kata membungkus menerangkan suatu benda yang dibalut, bisa dengan kertas, plastik, dan lain-lain, sedangkan kata mengenakan menerangkan memakai pakaian seperti terlihat dalam kalimat berikut.

$$
\begin{aligned}
& \text { Ibu }\left\{\begin{array}{c}
\text { membungkus } \\
* \text { mengenakan }
\end{array}\right\} \text { nasi dengan daun } \\
& \text { pisang supaya lebih awet dan harum. }
\end{aligned}
$$

Ibu $\left\{\begin{array}{c}\text { mengenakan } \\ * \text { membungkus }\end{array}\right\}$ kebaya pada saat hari ibu.

Makna konotasi, emotif, atau nilai rasa yang lebih kasar ditimbulkan oleh kata membungkus sebagai bentuk pengganti dari kata mengenakan.

b. Mahasiswa itu sudah $\left\{\begin{array}{c}\text { terjangkiti } \\ \text { terkena }\end{array}\right\}$ budaya konsumerisme yang berlebihan.

Dalam kalimat di atas, kata terjangkiti dipilih sebagai disfemisme dari kata terkena. Kata terjangkiti digunakan untuk memberikan penekanan atau mengeraskan makna pada kata terkena. Dilihat dari cakupan maknanya, distribusinya kata terjangkiti dan terkena berbeda. Kata terjangkiti memiliki cakupan makna yang lebih sempit dari kata terkena. Kata terjangkiti menerangkan ditulari penyakit atau virus, sedangkan kata terkena menerangkan sudah kena oleh sesuatu. Hal ini dapat dilihat dari kalimat berikut.

Orang itu sudah $\left\{\begin{array}{c}\text { terjangkiti } \\ * \text { terkena }\end{array}\right\}$ virus flu burung.

Orang itu $\left\{\begin{array}{c}\text { terkena } \\ * \text { terjangkiti }\end{array}\right\}$ peluru nyasar ketika sedang mengendarai motor.

Dilihat dari kolokasinya, kata terjangkiti dan terkena memiliki kelaziman yang sama, hanya saja kata terkena tidak hanya mengacu kepada makna tertular penyakit saja, bisa juga kepada hal-hal yang lain. Makna konotasi, emotif, atau nilai rasa yang lebih kasar ditimbulkan oleh kata terjangkiti sebagai bentuk pengganti dari kata terkena yang halus/netral.

c.Masalah sosial politik ekonomi bangsa ini lagi $\left\{\begin{array}{c}\text { sekarat } \\ \text { tidak baik }\end{array}\right\}$.

Pemakaian kata sekarat dalam kalimat di atas merupakan eufemisme dari frasa tidak baik yang digunakan untk memberikan penekanan pada makna keadaan sosial politik ekonomi yang lagi tidak baik. Pengungkapan ini ditekankan dengan kata sekarat. 
Dilihat dari cakupan maknanya, distribusi kata sekarat dan frasa tidak baik berbeda. Kata sekarat memiliki cakupan makna keadaan saat menjelang kematian, sedangkan frasa tidak baik memiliki cakupan makna yang sama, hanya lebih luas dari dari kata sekarat. Hal ini dapat dilihat dari kalimat berikut.

$$
\text { Mencuri adalah sikap yang }\left\{\begin{array}{c}
* \text { sekarat } \\
\text { tidak baik }
\end{array}\right\} \text {. }
$$

Kondisi orang itu $\left\{\begin{array}{c}\text { sekarat } \\ \text { tidak baik }\end{array}\right\}$ setelah tertabrak mobil.

Dilihat dari cakupan maknanya, distribusi kata sekarat dan frasa tidak baik berbeda. Frasa tidak baik lebih luas dari kata sekarat. Kata sekarat mengacu kondisi fisik dan keadaan yang sulit, sedangkan frasa tidak baik untuk menerangkan sikap/perilaku. Dilihat dari kolokasinya, kata sekarat dan frasa tidak baik memiliki kelaziman yang berbeda. Kata sekarat menerangkan keadaan yang hampir mati, sedangkan frasa tidak baik menerangkan situasi yang tidak baik dalam kondisi maksimal.

Makna konotasi, emotif atau nilai rasa yang lebih kasar ditimbulkan oleh kata sekarat sebagai bentuk pengganti dari frasa tidak baik yang halus/netral. Contoh yang serupa dapat kita lihat pada kalimat berikut.

a. Angkatan baru berhasil $\left\{\begin{array}{c}\text { menumbangkan } \\ \text { melengserkan }\end{array}\right\}$ rezim orde baru.

b. Krisis ekonomi cukup lama $\left\{\begin{array}{l}\text { mencekik } \\ \text { menindas }\end{array}\right\}$ negeri ini.

c. Kekayaan ibu pertiwi telah $\left\{\begin{array}{c}\text { diperas } \\ \text { diambil }\end{array}\right\}$.

d. Orang-orang mengelilingi tokoh tersebut beberapa diantaranya mempunyai moral yang $\left\{\begin{array}{c}\text { cacat } \\ \text { rusak }\end{array}\right\}$.

\subsection{Bentuk Disfemisme}

3.4.1 Kata dan Kata

Bentuk disfemisme kata dan kata dapat dilihat dalam beberapa kata berikut.

a) Kata menggadaikan disfemisme dari kata menyerahkan b) Kata memberontak disfemisme dari kata menolak

c) Kata dirampas disfemisme dari kata diambil

d) Kata menuntut disfemisme dari kata menginginkan

\subsubsection{Kata dan Frasa}

Bentuk disfemisme kata dan frasa terlihat dalam kata dicabut disfemisme dari frasa tidak berlaku

\section{PENUTUP}

\subsection{Simpulan}

Hasil penelitian menunjukkan bahwa pemakaian eufemisme dan disfemisme pada kumpulan feature dalam buku Campus Undercover memiliki kecenderungan memberikan penghalusan pada makna yang ingin disampaikan sehingga lebih enak untuk didengar seperti frasa tidak jujur yang merupakan eufemisme dari kata bohong. Selain untuk menghaluskan, feature ini juga menggunakan metafora, misalnya frasa daun muda yang merupakan eufemisme dari kata wanita muda. Selain untuk menghaluskan, penggunaan tersebut juga dapat membuat penyajian menjadi lebih menarik karena bersifat mengisahkan/menceritakan.

Hasil analisis menunjukkan bahwa tidak semua eufemisme (bentuk pengganti) mengandung metafora untuk menghaluskan makna, sedangkan pada disfemisme (bentuk pengganti) mengandung hiperbola karena merupakan makna yang mengeraskan, melebih-lebihkan, dan untuk menimbulkan rasa yang kasar. Dapat disimpulkan bahwa sepasang sinonim tidak memiliki arti yang persis sama karena arti sebuah kata dapat lebih luas, lebih sempit, persis sama atau hanya mempunyai arti sebagian yang sama.

\subsection{Saran}

a) Hendaknya ada kelugasan dalam penyampaian maksud dalam feature-feature tersebut yang disesuaikan dengan budaya dalam masyarakat.

b) Penelitian ini dapat dijadikan bahan pengajaran bagi guru dalam pengajaran bahasa dan sastra Indonesia khususnya tentang eufemisme dan disfemisme. 
Muhammad Fadely: Eufemisme dan Disfemisme pada Feature-Feature Karya Ruslan Ismail Mage

\section{DAFTAR PUSTAKA}

Arikunto, Suharsimi. 1998. Prosedur Penelitian Suatu Pendekatan Praktek. Jakarta: Rineka Cipta.

Badudu, Yus. 1989. Inilah Bahasa Indonesia yang Benar II. Jakarta: Gramedia.

Cahya, Inung. 2012. Menulis Berita di Media Massa. Yogyakarta: PT Citra Aji Parama.

Chaer, A. 2002. Pengantar Semantik Bahasa Indonesia. Jakarta: Rineka Cipta. 2010. Bahasa Jurnalistik. Jakarta: Rineka Cipta.

Kusumaningrat, Hikmat. 2012. Jurnalistik Teori dan Praktik. Bandung: PT Remaja Rosdakarya.

Keraf, Gorys. 1990. Diksi dan Gaya Bahasa. Jakarta: Gramedia. 1993. Komposisi: Sebuah Pengantar Kemahiran Berbahasa. Ende Flores: Nusa Indah.

Masri, Ali. Dkk. 2001. "Kesinoniman Disfemisme dalam Surat Kabar Terbitan Palembang” dalam jurnal Lingua, Vol 3 (1): $62-69$.

Natawidjaja, P Suparman. 1986. Apresiasi Stilistika. Malang: Intermasa.

Pateda, Mansoer. 2001. Semantik Leksikal. Jakarta: Rineka Cipta.

Romli, Asep Syamsul M. 2009. Jurnalistik Praktis Untuk Pemula. Bandung: PT Remaja Rosdakarya.

Sudaryanto. 1993. Metode dan Aneka Teknik Analisis Bahasa. Yogyakarta: Duta Wacana University Press.

Sumadiria, AS. 2005. Jurnalistik Indonesia. Bandung: Simbiosa Rekatama Media.

Sunarso. 1998. "Eufemisme dan Latar Belakangnya” dalam majalah Humaniora (19): 70—76.

Tarigan, HG. 1995. Pengajaran Semantik. Bandung: Angkasa.

Vehaar, J.W.M. 1998. Pengantar Linguistik. Yogyakarta: Gadjah Mada University Press.

Wibowo, Wahyu. 2007. Berani Menulis Artikel Babak Baru Kiat Menulis Artikel Untuk Media Massa Cetak. Jakarta: Gramedia. 
Muhammad Fadely: Eufemisme dan Disfemisme pada Feature-Feature Karya Ruslan Ismail Mage 